\title{
ACTORS AND DISCOURSES IN THE CONSTRUCTION OF HEGEMONY
}

\author{
Monica Heller
}

\begin{abstract}
In this paper, I will examine one aspect of a Gramscian notion of hegemony, one which focusses on the way in which hegemony is about "collectively attaining a single cultural "climate"", at least in part through language. This assumes discursive struggle in which some views end up marginalizing others. I will examine this struggle in terms of some of the ways in which the trajectories of actors and of discourses are connected, such that discursive resources are (or are not) available to actors with different positions with respect to unequally distributed symbolic and material resources, and are used in practice in ways which make sense given the sets of interests these actors have. This attempt at operationalizing an ethnography of hegemony is based on an analysis of discursive shift in between ethnonational forms of hegemonic discourse and practice being challenged by commodification, economic networking, and multiple affiliations, under conditions of economic shift from primary and secondary resource economies to tertiary ones, and of the reshaping of the State's relationship to civil society and the private sector. It has specifically to do with current shifts in ideas about what constitutes the category francophone in Canada, or put differently, what it might mean to do being "francophone". In particular, I will examine the ways in which the institutionalized structures related to that categorization have been called into question by ongoing political economic change, and how actors involved in those structures act in, on and through the process of change to produce new ways of doing la francophonie, at least on the local level.
\end{abstract}

Keywords: Actors, trajectories, structuration, Canada, institutional ethnography

\section{Operationalizing an ethnography of hegemony}

"An historical act can only be performed by "collective man", and this presupposes the attainment of a "cultural-social" unity through which a multiplicity of dispersed wills, with heterogeneous aims, are wielded together with a single aim, on the basis of an equal and common conception of the world, both general and particular, operating in transitory bursts (in emotional ways) or permanently (where the intellectual base is so well rooted, assimilated and experienced that it becomes passion). Since this is the way things happen, great importance is assumed by the general question of language, that is, the question of collectively attaining a single cultural "climate"." Antonio Gramsci (1971: 349)

In this paper, I want to take up some elements of what I understand Gramsci to be talking about, with a focus on the ways in which hegemony is about "collectively attaining a single cultural "climate"", at least in part through language. (There is much more to be 
explored about these few lines, for example, the link to emotion, but that is beyond what I can usefully do here.)

Gramsci's and others' attention to hegemony has been hugely influential, but often largely theoretical or devoted to broad-scale analyses of the State and civil society. The question remains of how all this actually happens, that is, of what the nature of the linkage might be between structures of domination, legitimizing and sense-making discourses, and social practices of various kinds, ranging from those which are the object of conscious reflection to those which are embodied and inexpressable. This is a place where I think ethnography, and some actualized version of the ethnography of communication, begins to look like a fruitful means of trying to answer that question. Because the first question is where, the second is who, and then we can get to the how, and, finally, the why.

Gramsci focussed on the nation-State, and much current work asking similar questions, such as that under the rubric of Critical Discourse Analysis, does the same. Ethnographic sociolinguistics has tended to focus on the institutions of what Gramsci might have thought of as civil society (institutions, such as medicine, education, the law), although frequently without what I take to be Gramsci's attention to the articulation between the State and civil society (but see Philips 1998). Here I will attempt an analysis of how a set of social actors work at achieving "a single cultural "climate", through language, in a civil society space. This also requires some thinking about the links between what happens in the here-and-now, and processes of social structuration (in Giddens' sense; 1984 ) in all their various degrees of institutionalization. However, such a wide sweep is obviously beyond the scope of what I could possibly hope to accomplish here. Instead, I propose to pick up one thread of this kind of web, to show what this might look like.

The specific dimension, or thread, I want to attend to here has to do with the ways in which the trajectories of actors and of discourses are connected, such that discursive resources are (or are not) available to actors with different positions with respect to unequally distributed symbolic and material resources, and are used in practice in ways which make sense given the sets of interests these actors have. The argument has several aspects:

First, hegemony doesn't fall from the sky; it gets constructed in ways that are more or less evident to the extent to which structures of domination are contestable. The case I will examine here is helpful insofar as it is a case of contestation and shift; such interstices or gaps render visible the process of construction of hegemony, that is, the undoing and reformulating of taken-for-granted discourses and practices in ways that serve new sets of interests, and which mask the emergence of new forms of power, that is, they render them invisible as new forms of power, and present them instead as necessary and consensual, indeed, natural and evolutionary, change. Central here is the role of interactional order as a means for accomplishing the contestation of old discourses and relations of power, and for replacing them with new ones. Not that coercion is absent (as we will see, someone eventually gets escorted out of his office and into the street), but it is hidden in favour of the manufacture of consent, to use Chomsky's phrase, or at least of the appearance of consent.

The second dimension of the argument has to do with what Philips (1998:216) calls the way that "language ideologies can and do cross fluid or ephemeral institutional boundaries". Much sociolinguistic or discourse analytic work focusses on moments, or texts, or specific sites, assuming a certain stability or autonomy of institutional, textual or 
interactional structure. As Philips points out, Gramsci, along with Bourdieu and Foucault, (as well as, I would add, Giddens), point instead to linkages, flows and connections as the heart of hegemonic processes. This is a methodological challenge, which I think ethnography is particularly well-placed to take up; the attempt here then is to select from a range of ethnographic tools (interaction analysis, textual histories, interviews, observation) to get at the flows (of ideas, discourses and actors) across time, space and institutional boundaries which allow us a broader view of how hegemony might work.

The third dimension is the specific nature of shifts in the shape of hegemony in late modernity. The strength of arguments based on national identity and cultural belonging are shifting to legitimizing discourses based on economic value, flexibility, mobility and multiplicity, as has been widely noted (cf. e.g. Appadurai 1996; Castells 2000). But again, these are not processes which are disconnected from the lives of individuals or the daily operation of institutions and from which agency is absent. We still need to understand who has control over the reshaping of legitimizing ideologies, under what conditions, and with what consequences for whom. The fundamental nature of the shifts in process call into question the existing bases of hegemony, setting off processes of contestation and struggle on shifting, new territory.

The case I will explore here is directly connected to this problem, since it is about the shift between ethnonational forms of hegemonic discourse and practice being challenged by commodification, economic networking, and multiple affiliations, under conditions of economic shift from primary and secondary resource economies to tertiary ones, and of the re-shaping of the State's relationship to civil society and the private sector. It has specifically to do with current shifts in ideas about what constitutes the category francophone in Canada, or put differently, what it might mean to do being "francophone". In particular, I will examine the ways in which the institutionalized structures related to that categorization have been called into question by ongoing political economic change, and how actors involved in those structures act in, on and through the process of change to produce new ways of doing la francophonie, at least on the local level. On the Canadian scene, this is a key domain of the cultural climate, and of the relationship between cultural climates and the other central element of hegemony, that is, the gaining of consent to cultural constructs which serve interests in the production and reproduction of relations of power.

Ethnolinguistic identity in general, and the opposition "English-French" or "anglophone-francophone" (or any number of the ways in which the opposition is expressed) in particular, are key structuring principles in Canadian society, serving notably to reproduce and legitimize social stratification, or to contest that reproduction. What counts as la francité is therefore one dimension of a cultural climate of consent to, or resistance against, the ethnicization of relations of power in Canadian society. And since it is, among other things, a site of resistance to anglophone power, it serves to illustrate more sharply and clearly than an exploration of "Angloness" might be, both how the ethnicization of power is lived, and how resistance and reproduction can both be part of

\footnotetext{
${ }^{1}$ My choice of label is, of course, not neutral, because no label can be, and the label itself has been in almost constant flux since the constitution of the category via the conquest of New France by Britain in 1763; I choose this one because for the period we are concerned with it has been the dominant one, and I would like to use it in as loose and as neutral a way as possible, under the circumstances.
} 
hegemonic practices. ${ }^{2}$ Indeed, here, while the sense of the case I will be examining is inscribed in English-French inequality, the content is more about struggles among participants within francophone discursive space than it is about relations across ethnolinguistic groups.

The specific case I examine here is a small cultural centre in a town in central Ontario. I do want to argue, based on ethnographic work in a wide variety of settings, that the case I will present here is fairly typical of what is going on in the world of francophone institutions in Canada in general, although of course each case has its specificities, and in many ways what we have to say about broader processes depends on the kinds of comparisons and links among sites that we are in fact able to make. ${ }^{3}$ For the purposes of this paper, I will leave aside the broader argument based on these historical and broad institutional linkages, and concentrate instead on the problem of what makes things tick in the here-and-now, that is, on the problem of how interaction and institutional processes are directly related on the ground (duly recognizing that I am leaving aside one of the central problems of structuration).

The specific argument I will build here is that changes in ideas about what it means to be francophone (or French-Canadian, or Franco-Ontarian, or bilingual, or whatever label seems to apply at specific times and for specific kinds of people) have gone through two major discursive shifts, from traditionalist to modernizing, and from modernizing to globalizing (Heller and Budach 1999). While these shifts have occurred to greater or lesser degrees, and with varying shapes, across francophone Canada, the broad outlines seem to consistently apply. Here I will track in particular the second shift as it is being constructed in one particular site of discursive production, a community cultural centre, which is relevant in terms of the nature of the institution in the production of discourse in and about francophone Canada, and in terms of the kind of community it is located in, one which has a symbolic significance for francophone Canada and which is typical in terms of the political economic changes it has undergone. As mentioned earlier, this particular shift is world-wide; the question here has to do with its local manifestations and consequences under conditions which raise particularly sharply the role of ethnonational affiliation in the globalized new economy.

I will link the trajectories of the social actors involved in this discursive space to the trajectory of the social institution in which they are involved, in order to explain why certain kinds of actors have access to this space and are able to control the construction of the discourse produced there, and in order to illuminate why certain discursive orientations make sense to certain kinds of people and not to others, in certain circumstances. In this

${ }^{2}$ An exploration of the perspective from the English side would be equally revealing, of course, but in some sense harder, since one of the hallmarks of dominant discourses is their ability to erase salient features. The kind of debates we will see here occur less frequently, and are less visible; from the centre, there can be, quite literally, nothing to say.

${ }^{3}$ The data presented here are drawn from a project funded by the Social Sciences and Humanities Research Council of Canada, the German-American Academic Council Foundation and the Association universitaire de la francophonie. The project, entitled Prise de parole: La construction discursive de l'espace francophone en milieu minoritaire (PIs: Monica Heller, Normand Labrie and Jürgen Erfurt), was conducted during the period 1996-2000 in Ontario and the Maritime provinces of Canada, in a wide variety of institutional and geographical settings. 
view, institutional processes are in some senses discursive genres, available to be exploited as communicative resources, or else obstacles to action that must be confronted or else accepted. The collective construction of single cultural climates is therefore not just the accumulation of many local ones, but rather, crucially, a question of the linkages among them in the context of available communicative resources.

\section{A community centre}

I will focus on one francophone community association located in a small town in central Ontario. The structure of the community association has a history in French-speaking Canada, as one of the structures of collective participation which marked the construction of collective identity, and appropriated the possibility of producing discourse relevant to the definition of might it might mean to be a francophone in Canada, or in any of its regions. The history is probably not very long; for something like 150 years after the conquest the Catholic Church was the principal mode of social organization, and the main source of discursive production. The lay elite did have other institutions and means of socialization, mainly through writing and through intellectual and literary circles, and in the $20^{\text {th }}$ century through a secret society, but these were usually tightly linked to the clerical elite and its discourse (Martel 1997; Heller and Labrie, in press). In any case, these formations need to be read as part of an ongoing struggle over the definition of the Canadian State, and over access to the power and resources it aimed (and aims) to control. In particular, a constant thread in the history of Canada has to do with struggles between English and French over the cultural shape of State and government, whether or not the debate was understood in those terms; while other groups, notably aboriginals, have obviously been part of this debate over the centuries, it has in fact been the English and the French who have had until recently enough power to engage each other on this terrain). This is a terrain of hegemony and counter-hegemony.

Many local community centres probably had their origin in fact through the counterhegemonic activities of the secret society, l'Ordre de Jacques Cartier. This society was active from 1926 to 1965, and was founded on a parallel with societies like the Orange Order and the Freemasons, which were understood to be mechanisms of reproduction of anglophone domination, and therefore of exclusion of the francophone community from positions of political and economic power (Laliberté 1983; Cyr 1964; Heller in press). While primarily composed of members of the lay elite, the clerical elite, and indeed the Catholic Church as an institution, were deeply involved. It is clear that the OJC embarked on a campaign of construction of collective identity and political and economic mobilization through the action of local cellules, and that one of the methods it preferred was the establishment in local communities of a social club which would act as the public face of the secret society. Its primary objective was the reproduction of a notion of being francophone which was organic and tightly bound to Catholicism, and legitimized on the basis of historicity, authenticity and tradition (cf. Hobsbawm and Ranger 1983). This collective identity would serve as the basis of solidarity and mobilization for the reproduction and expansion of the elite (mainly through Catholic education) and its entry into domains of power currently closed off to them by the dominant anglophones. This was understood of course as being in the broadest possible collective interests, not in those of 
the elite alone.

The numbers and orientation of social and cultural centres, clubs and associations grew however markedly in the late 1960s and 1970s, in provinces where francophones formed a demographic minority (Farmer 1996). The reasons for this have largely to do with the collapse in the early 1960s of the strategy of social mobility constructed by the lay and clerical elite (see Heller and Labrie in press for a discussion of the reasons for this collapse). What we think of as a traditionalist discourse was largely taken over by a modernizing one, focussing on the deployment of a widespread discourse of national liberation, the appropriation of political power, and massive democratic entry into the zones of economic and political power in the modern world (Heller and Budach 1999; Heller and Labrie in press). In francophone Canada, this discourse emerged first in Quebec, and fragmented the previously homogeneous notion of francophone Canada (Martel 1997). The rest of francophone Canada attempted to follow suit, but in the end the nation-state strategy of Quebec was impossible to realize in the other areas. Instead, we see the emergence of a form of institutional nationalism (Heller 1999), in which the push for the construction of nationally, culturally and linguistically homogeneous social space is expressed through institutions rather than territorial states. In some sense, the counter-hegemonic project shifts as well, insofar as the long-standing objective of francophone entry - as francophones into existing dominant structures becomes the most salient dimension of the discourse, marginalizing some earlier, somewhat more utopian counter-hegemonic projects, such as those of some influential members of the $19^{\text {th }}$ century clergy, who more radically rejected dominant values and life modes.

The problem became centrally one of maintaining the affiliation base which serves as a source of power, while embarking on a less radical project. Social and cultural associations were among the institutional types to emerge in this period, and have been important spaces of construction of discursive positions, and of neutralization of some of the central contradictions between difference and participation in mainstream institutions which were its hallmark. A very large part of their funding came from provincial and federal government sources concerned to demonstrate that Quebec need not become independent in order for francophones to be able to exercise collective rights in North America, that is, who shared a concern that difference not challenge the democratic legitimacy of the State.

The specific centre we examine here is typical of this history. Its antecedents lie in various attempts in the 1950s on the part of the local cell of the OJC to found a social club, the last of which was successful, as well as in other OJC-related elite associations. However, in its current form, it was founded in the 1970s, and played a very important role in what was the defining modernizing struggle of the community, a fight for the establishment of a French-language high school to replace the bilingual one which had been in place since the 1960s (before that francophones rarely finished high school; when they did they left the community to attend Catholic convent and seminary schools, as was the case across Canada). Its legitimacy is linked to the legitimizing discourse of the school struggle, and is based on the idea of the continuous occupation of the region by a homogeneous group, united throughout history by struggle against francophone domination. Thus the foundations of the traditionalist discourse are taken up, appropriated and reoriented in a modernist cause. This is clearly expressed in a text commissioned by the provincial lobbying association to commemorate the school struggle (and indeed to 
extend its relevance across other contexts; the event has become a key reference point in modernist Franco-Ontarian history, in part through the distribution of this text) :

Sur les bords de la Baie [...], que Champlain [l'acteur clé de la colonisation de la NouvelleFrance] visita en 1615, s'élève [nom de la localité], la plus ancienne ville de l'Ontario, la première d'expression française. Ce deuxième titre d'ancienneté se garde au prix de nombreux sacrifices, de querelles politico-religieuses, voire même de luttes épiques. Les pionniers travaillant sous le zèle du Père Laboureau, dès 1873, les parents francophones dirigés par le Père Brunelle, au début du siècle, et les étudiants franco-ontariens opposés aux volontés assimilatrices de leur conseil scolaire en 1979-1980, témoignent tous d'une vie française enracinée [dans la région], parfois en difficulté mais toujours tenace.

(On the edges of the Bay (...), which Champlain [a key actor in the colonization of New France] visited in 1615, sits [name of the community], the oldest town in Ontario, the first to be Frenchspeaking. This second title of age has been maintained at the price of many sacrifices, of politicoreligious quarrels, and even of epic struggles. The pioneers working under the zeal of Father Laboureau, already in 1873, the francophone parents directed by Father Brunelle, at the beginning of the century, and the Franco-Ontarian students opposed to the assimilating will of their school board in 1979-1980, all bear witness to a French life rooted [in the region], sometimes in difficulty but always tenacious. (Sylvestre 1980: 9)

The association was active throughout the 1980s, not without some controversy and difficulty, notably over whom it did or did not represent. The so-called "school crisis" brought into the open a long-standing difference of interest between the local elite and the local working class, and between the various small communities in the area. Notably, the elite based in the village which acts as the heart of the francophone community, in alliance with the elite elsewhere, has always fought for the construction of a homogeneous collective identity, lamenting the assimilation of their fellow putative community members who live more of their lives in English-speaking networks, structures and activities. The working class francophone inhabitants of the francophone village tend to stay out of public debate, but do rely on kin and friends to reproduce their control over local markets through French (notably in the increasingly lucrative market for construction and maintenance of upscale vacation homes). Other workers in more English-dominated towns feel rejected and marginalized by their elite. This resulted in an ongoing problem for modernizing ethnonationalist institutions, namely how to include people who should be included but who mysteriously refuse to show up, or if they do show up, who mysteriously refuse to collaborate in the fight for the construction of the elite's vision of the community.

The central core of the association can be described as follows. It consists of a physical space, and a loose network of people, and links to other organizations. In terms of space, it occupies a former municipal building on the main street of one of the region's small towns; the town has always been dominated by anglophones, but has drawn francophones from the surrounding villages and countryside to its industries for over 100 years. The choice of site is significant: In many ways, it is a symbolic statement to the English population that francophones intend to take part in the public space of the town, as francophones (rather than through English and English-speaking networks). It is meant to represent all francophones of the region (the limits of which have expanded over the years as communications and travel become easier), which has been operationalized to mean essentially anyone who self-selects as long as they permit the institution to function publicly in French (the question of what counts as French is a vexed one, as we will see 
below, mainly because it divides the elite from the rest of the population, while inadvertently allowing the inclusion of anglophones with schooled French). The legitimacy of the representation is based on the annual election by the "community" of a conseil d'administration. The association has been linked for many years to a number of other institutional networks, such as the local francophone newspaper, a provincial network of lobbying groups, a provincial network of adult literacy centres, a national association of francophone community radios, and a provincial association of francophone community centres. The exact nature of these ties has shifted over the years.

The association has faced a number of struggles, and many contradictions, the first among them likely being the problem of representativity. As long as the government continued to fund such associations, it was largely possible to continue to struggle with such contradictions without them undermining the fundamental legitimacy of the associational structure. However, centres such as this one ran into some serious trouble in the 1990s, for reasons which have in part to do with the dissolution of the political economic basis of the modernizing discourse, and in part with the kinds of paradoxes it created itself. Thus, part of this trouble had to do with the fact that the association's funding came from government sources, which were rapidly drying up as a result of widespread neoliberal rationalization and privatization schemes (see Bagaoui et Laflamme 1997 for a discussion of the impact of this process on the francophone associational structure in northern Ontario). Indeed, in 1996, the government announced a new reduced funding plan which required province-wide consensus, thereby triggering a massive struggle for access to the limited resources left, in each and every province affected. Part of the trouble had to do with the still disaffected traditionalists, who were ostensibly represented by this association but who stubbornly refused to turn up for all but local, cultural and social events. Finally, part of the trouble had to do with the major shifts in the economic organization of the region, which was increasingly drawn into larger economic circuits, into the orbit of demographically exploding urban centres farther south, and into new ways of making a living for which it was unprepared. The economy increasingly turns on new service and information activities based in the larger towns farther south, despite a building boom fuelled by the newly rich or almost retired (mainly from Toronto, but also from as far away as Russia) who are building themselves expensive vacation or retirement homes in a region felt to be particularly bucolic, and despite new attempts to invest in local community development, notably through tourism. The upshot is that the funding base of the association is crumbling, there are increasing pressures on the association to demonstrate that it does indeed represent a population which is only becoming less and not more diversified, and economic changes in the region mean that even the interests of those who have always been centrally involved are changing, away from political militancy and towards local economic development.

These are conditions requiring regrouping, that is, either finding a new basis for maintaining old ideologies of identity, or finding new ways to redefine the collectivity, which might or might not preserve existing power structures. My analysis here is that what emerged, with only local and well-contained struggle, was the redefinition of la francite in ways which allowed the association to persist and its members to retain their positions of power. The centre redefined itself away from the political voice of the local manifestation of a homogeneous nation, spearheading a mission to maintain language and culture as defined largely by an elite, and towards an agent of local economic development, at the 
service of a set of people who are free to define themselves and need not have much in common besides a set of economic interests, some kind of (non exclusive) affiliation with an idea of Frenchness and an ability to function in (some undetermined kind of) French.

At any rate, this is what it looks like from the outside in, or more precisely once a lot of threads have been followed and tied together. From an ethnographic perspective, we had hints of changes over the three years we spent going and coming from the area, from interviews, from sitting in on and recording association executive committee meetings, reading documents produced by the association from the late 1970s to the present, reading the community newspaper, and following what was happening simultaneously in other sites organically connected to this one (such as the local literacy centre and its own institutional province-wide network, or meetings involving the province-wide political lobbying group with which the centre is affiliated, as well as its counterpart in New Brunswick, or the evolving French-language minority school system in Ontario). There is of course a lot that we know happened but which took place beyond our reach (such as telephone conversations between members of the association), as well as many things which we never found out about at all. Given these constraints, it is still possible to construct some links.

\section{The local dimensions of change: The actors}

Here I would like to first introduce the actors, since their positions and interests are important to understanding why they do what they do. Generally speaking, the key actors are people who have been invested in developing, or who have profited from, a modernist view of la francité. These tend to be members of the local elite (generally members of wealthier farming families who had access to education, and who grew up in the mainly francophone rural inner zones of the region), or francophones from other areas of the province or the country where francophones are more numerous, where militant ideologies have had a stronger base, and who are brought into the region to work in francophone institutions (especially education). They seek to extend their perspective to all putative members of the group, since that is of course the basis of their legitimacy, despite the fact that many of those putative members feel disenfranchised and misunderstood.

The actors involved in the centre in institutional terms include the elected members of the conseil d'administration, and the employees of the centre. The elected members tend to be drawn from the same categories of actors over the years. The president, Émile Valois, ${ }^{4}$ has remained in office for quite a while; he was born in the region, has a modernist job connected to the implementation of government legislation regarding services to francophones, and is also the president of the local chapter of the provincial lobbying group. Other members have come and gone, staying a year or two or maybe three; they tend to be drawn from the ranks of the elite, often active or retired members of the education profession, frequently professionals who came to the region from a part of Canada where francophones form a larger percentage of the population, and sometimes members of local historically-prominent families. Indeed, this can pose a problem when it comes to election time, as the (employed) directeur-général points out at a meeting when the recruitment of

\footnotetext{
${ }^{4}$ All names have been changed.
} 
new candidates for upcoming elections is discussed:

\begin{abstract}
je suggère que on pourrait vraiment regarder dans le monde non impliqué là) si on regarde trop souvent c'est toujours quelqu'un qui (xx) beaucoup de personnes dans le syst ème scolaire ou rattachées indirectement indirectement à ça ou rattachées à des organismes/y a quand même un peu de tout comme à l'extérieur euh de nous/les les TLM (= Toujours Les Mêmes) (rires)
\end{abstract}

(I suggest that we could really look at the people who aren't involved [discourse marker]/if we look too often it's always someone who (xx) many people in the school system or connected indirectly indirectly to it or connected to organizations/there is anyway a bit of everything like outside uh of us/ the the ATS (=Always The Same) (laughter) ${ }^{5}$

(This issue never actually gets addressed by the council, in this meeting or later, at least not in the data we have.)

The other members of the centre are Bernard, its directeur-général, and a varying number of employees, depending on funding. In the period we were there, there were usually three (all female), including a secretary and two employees working on specific projects. Bernard is an important actor for the story that unfolds here. He is a product of a local family, although not part of the elite, but still connected to the francophone history of the place. His account of himself in an interview with us is that he got converted to a modernist perspective through his experience of the school crisis, in which he became a central figure, acting for example as media spokesperson.

Since then he has been involved over two separate periods with the centre. It is important to note that Bernard played a key role in a major reorganization of the centre in the early 1990s, at a time when it looked like the tensions over representativity, and the difficulties in adapting to changing conditions, might destroy it altogether.

${ }^{5}$ Interestingly, Bernard also has a theory as to why other people don't present themselves as candidates, namely that the norms of language use which prevail in the association are so defined by the elite that they act as mechanisms of exclusion:

peut-être qu'i(ls) se sentent intimidés $(x)$ parce qu'i(l) faut quand même $(x)$ bon français [...] comme j'ai déjà entendu des gens qui parlent pas de passer proche là mais des gens qui sont venus à des réunions qui se sont exprimés pis y avait pas le français le meulleur pis $i(l s)$ ont fait rire d'eux autres / $(x x)$ i(ls) en parlent "non j'y retourne pus!/ Là j'ai fait rire de moi (moé)/(xx) parler mon français/ alors qu'i(ls) mangent de la marde/ (rire) j'y retournerai jamais"// y a des gens comme ça/ mais y a bien des gens qui ont pas vécu cette chose-làl/ on aurait besoin de aller les chercher puis i(ls) pourraient peut-être contribuer beaucoup

(maybe they feel intimidated (x) because a good (quality) French is necessary just the same/ [...] like I have already heard people who speak not to get close [discourse marker] but people who came to meetings who expressed themselves and they didn't have the best French and they got laughed at/ (xx) they talk about it "no I'm never going back// [discourse marker] I got laughed at/ (xx) speaking my French/ so they can go to hell (lit. eat shit)/ (laughter) I'm never going back"// there are people like that/ but there are many people who haven't had that experience// we have to go find them they could contribute a lot

Nonetheless, Barnard's analysis does not lead him to call the association's language norms into question; rather he suggests avoiding people who have had a bad experience, and perhaps obliquely suggests that the council might think again how to treat them if they do choose to participate. 
His vision of his role seems to have been forged in the militancy of the school crisis. During meetings he takes a leading role; most of the time of the meetings we attended in the first part of our research involved Bernard providing information to council members, information which largely concerned his efforts to obtain funding for the centre's infrastructure or for its projects (remembering that a significant portion of the centre's operating grant has long come from government grants). These efforts are often characterized as revolving around personal ties between Bernard and relevant agents, and as based on Bernard's unique capacities as a social actor.

The following is an illustrative excerpt from one meeting held in November 1998. Bernard describes a dilemma he (and therefore the centre) faces regarding a government infrastructure grant. The centre has been planning to open a music school; this is a typical activity for a modernist perspective focussing on the use of culture to bring together francophones into a space where French is the language used, and simultaneously on the construction of francophone institutions to parallel anglophone ones (the idea is that if local francophone children want to take afterschool music lessons, they currently have to do so in English, thereby contributing to the marginalisation of French in their lives). In order to run a music school, they need a piano, and so they included one in the grant budget. However, the music school has not yet gotten off the ground (in part because of difficulties in finding a teacher). The question is whether Bernard can use his personal ties with the responsible government agent to get the funds transferred to another budget item (see notably his formulation of the problem largely in terms of the first person singular, as representative of the collective on; and the use of the first name to identify the agent).

Bernard: (...) au ministère, une des parties de l'octroi c'est qu'on avait prévu acheter une piano (...) si (...) on avance pas avec l'école de musique, je vais être obligé d'aller voir Maryse [l'agente gouvernementale responsable du dossier] et d'avoir la permission, est-ce qu'on peut réassigner cette dépense à quelque chose d'autre, si elle ne l'approuve pas comme tel ça veut dire qu'il va falloir peut-être le retourner au gouvernement, je vais tout faire pour pas qu'on retourne l'argent au gouvernement, on en a trop de besoin (...)

(Bernard: (...) at the Ministry, one of the parts of the grant is that we had planned to buy a piano (...) if (...) we make no progress with the music school, I will be obliged to go see Maryse [the government agent responsible for this file] and get permission, can we reassign this expense to something else, if she doesn't approve [it] as such that means we might have to return it to the government, I will do everything I can so that we don't return the money to the government, we need it too much $(\ldots)$

Bernard thus clearly had a personal stake in the centre, one that was translated into major investments of his time and energy, a personal identification with the centre and the community it is meant to represent (he remained throughout the 1990s one of the key persons journalists interviewed for stories about francophones outside Quebec) and an understanding of his job as much more than mere wage labour. This stance, which in many ways saved the centre in the early 1990s, became the source of conflict less than 10 years later, as the centre continued to try to adapt to the cuts in government funding, to deal with the class conflicts within the community, and more broadly with the local economic changes that were changing the community's source of livelihood and the nature of its population. 


\section{The local dimensions of change: Actions}

In this section, I will explore some of the largely interactional processes which were at the heart of changes in the centre's orientation, mode of operating and ideological representation of itself, and therefore of the collective identity it is meant to symbolize (or perhaps more strongly, to materially constitute). I do not have access to their origins; I can only say that they began to become visible to us over the course of a series of meetings of the conseil d'administration, in which new content appeared on the agenda. First, in early 1998, it became clear that more and more time was being spent in meetings discussing information provided by Bernard regarding closed government programs, budget cuts and other forms of retrenchment which meant that the centre would no longer have access to the funds it had enjoyed in the past. Here is one example (note again the emphasis on personal persuasion):

Bernard : [...] ce qui nous amène quel quand on est arrivé à la fin de l'exercicel et si on se base sur le même montant euh connu du (ministère)/ ben là euh i(l) nous manquait de l'argent/ et puis alors qu'est-ce qu'on a conclu qu'on ferait si (xx) la demande 120195 (au ministère) ? le deuxième chiffre en l'air làl/ euh on va-tu l'avoir on le sait pas/mais on a soumis une demande et ça doit être par la lettre qu'on vous a remis que on essaie très fort de les convaincrel/ la radio communautaire c'est un besoin très important pour nous// on s'est fait couper l'herbe sous les pieds complètement quand qu'i(ls) nous ont enlevé l'octroi de 25000 du (xx)/ sinon nos chiffres balanceraient// et on compte que (le ministère) va nous octroyer plus qu'i(ls) nous ont envoyé euh cette année/ si non/ lorsqu'on ( $x$ ) la réponse de ça/ c'est une enqu êtel pourquoi revenir comme on a fait à toutes les années pis revoir les affaires / (xx) (à qui on envoie cet argent-là?)/ on nous répond on la trouve ailleurs// alors c'était le mieux qu'on pouvait faire

([...] which brings us that/when we got to the end of the fiscal year/ and if we base ourselves on the same amount uh known from the (ministry)/ well there uh we were short of money/ and so what we concluded what we would do if (xx) the request for 120,195 (to the ministry)? The second figure up in the air [discourse marker]// uh will we get it we don't know/ but we submitted a proposal and it should be by the letter which we gave you we tried very hard to convince them// the community radio is a very important need for us// we got the rug pulled out from under our feet (lit. we got the grass cut under our feet) completely when they withdrew the grant of 25,000 from the (xx)/ otherwise our figures would balance// and we count on (the ministry) granting more than they sent us this year/ otherwise/ when we (x) the answer of that/ it's a enquiry/ why come back like we have every year and look at things again/ (xx) (to whom do we send that money?)/ they answer us we find it somewhere else// so that was the best we could do)

Second, it became clear that what funds remained available would be subject to increasing constraints:

Bernard : I(l) faudrait avoir les preuves de consultation et de concertation aupr ès de la communautél et de maximiser les partenariats/ minimiser les co ûts d'administration et d'efforts d'autofinancement

(It would be necessary to have proof of consultation and collaboration with the community/and to have as many partnerships as possible/as few costs as possible and of self-financing efforts)

Clearly, current modes of operating were not going to work any longer. Interestingly, the first move the conseil made was not to provide new directives to Bernard, but to revisit 
the role of the conseil and the directeur-général, and the organization of the ways the actors directly involved in the centre would operate. This first phase of response constituted a struggle between the established modes, in which Bernard was free to design his role, and negotiated with the conseil specific priorities within a narrow, ideologically-delimited frame of existing options (what kinds of social, cultural and political activities would the centre pursue and support? How would it go about gaining or maintaining the resources necessary to pursue them?); and a newly emerging vision in which power to define orientation would shift from the staff (and specifically the $D G$ ) to the conseil, which would be responsible for directing employees.

Three threads begin to emerge. First, the conseil sets up a parallel body, loosely linked to it and with which it can act in partnership, and which is explicitly devoted to a form of activity in which cultural and social centres previously never imagined, namely local economic development. It is (still) run by someone from the community originally, who recently returned, having retired from a long career in international development with governmental and paragovernmental agencies. This organization has the mandate of "développement de biens et de services novateurs et de création d'entreprises et d'emplois (development of innovative resources and services and creation of companies and of jobs)" (as cited in an article in the local French-language newspaper, the Gout de vivre, 20 January 2000: 6). In this discourse of resources (biens), language is less about identity and pride, about rights and struggles, and more about market value. In the same text, the sentence about resources and services ends thus: “... d'entreprises et d'emplois qui montrent la valeur ajoutée des francophones et des bilingues de la (nom de la région) où l'on refl ète leur impact considérable sur la vitalité de la région (of companies and of jobs which show the added value of the francophones and the bilinguals of the (name of the region) where it is reflected their considerable impact on the vitality of the region)". French is important because it will help the entire region emerge from its economic slump. French is important because it has economic "added value". And francophones are important because without them, the region would have no claim to being able to provide that added value.

This presages a discursive turn that the centre itself will take, as we shall see. However, that discursive turn emerged only in the process of restructuring the centre, allowing it a new base for redefining its vision and the nature of its role. This process began with the proposal to institute formal job descriptions for the staff. In and of itself, this introduces a new idea into the discursive space of the centre, namely that working for such a centre can be primarily seen as a job, and not as a commitment to a cause. It also shifts power from the DG to the CA, providing the basis for the CA to make decisions regarding hiring, performance evaluation and eventually firing, none of which were previously formally institutionalized. Significantly, as we will continue to see, this entire process is based on the workings of bureaucracy, legitimized by the notion that the CA constitutes an elected body, and can act (facelessly) as representative of the community. In this vision, la francité is less and less about national heroes and causes, and more and more about community development.

In November 1998, the question of job descriptions appears on a meeting agenda, and immediately triggers a discussion about the implications regarding shifts in roles and responsibilities: 
qu'on met $4 C$ en avant de $4 B$ parce que je pense que j'aimerais rentrer en huis clos au besoin avec les tâches du personnel ok/ ça fait qu'on procède à 4 C avant $4 B$ si ça va? Oui Rosanne?

Rosanne: $j$ 'ai une question/je suis pas très familière avec les conseils d'administration alors je me demandais je me posais une question/ est-ce que c'est vraiment notre rôle de de regarder ça les les tâches des employés/ ou si c'est plutôt le rôle du directeur?

[...]

Émile: moi moi ma réaction là-dessus ça seraitça serait risquer votre responsabilité comme membre du CA parce quel si vous pouvez le fairel mais les décisions de votre directeur général ou l'administration rapporte directement au conseil d'administration comme responsabilité des décisions qui ont été prises [...]

(Émile: before we proceed with the agenda/ I'd like to suggest your consideration/ that we put 4C before $4 \mathrm{~B}$ because I think that I'd like to go into a closed meeting if necessary with the staff tasks ok/ so we proceed to $4 \mathrm{C}$ before $4 \mathrm{~B}$ if that's ok? / yes Rosanne?

Rosanne: I have a question/ I'm not very familiar with administrative committees so I was wondering I was asking myself a question/ is it really our role to to look at that the the tasks of the employees/ or is it rather the role of the director?

[...]

Émile: me me my reaction on that it would be it would be risking your responsibility as a member of the CA because/ if you can do it/ but the decisions of your director-general or the administration is linked directly to the administrative committee as responsibility for the decisions that got taken [...])

Émile's first job, then, is to bring everybody on board. His formulations are voiced in a way such that his suggestions are transformed into collective, consensual moves (I'd like to suggest your consideration; if that's ok?). Rosanne is clearly tentative in her challenge to the implications of such a move (I'm not very familiar with administrative committees; I was wondering I was asking myself a question) and through the subsequent formulation of her concern as a question, she permits Émile to take a position as authoritative answerer. Émile answers through an appeal to institutional reality: Whether we like it or not, the buck stops here. Morally, we must assume the "responsibility" of the position to which we were elected. Émile thus provides a moral basis of legitimation for the changes the CA is about to institute.

The major concern that Rosanne raised in November then takes on a life of its own. Indeed, the model of governance is at issue. The CA decides to revisit this question explicitly, and to formally adopt a governance model that will guide its functioning in the future. Someone obtains management training documents (our data do not show who or how), and all the members are asked to read them. It is significant that there is seemingly a consensus that the appropriate way to handle this issue is through bureaucratic means inspired by the private sector.

The models provided in the documents, and which essentially cover varying degrees of power to be concentrated in the hands of the council or the director-general, are discussed at a council meeting held in April 1999. As the discussion unfolds, one member raises the issue of this relationship and how to handle it in the context of broader ideological orientations; specifically, the problem is that the council is raising the possibility of curtailing the DG's independence for reasons which are stated as bureaucratic and democratic (better to have elected members make decisions; the council remains but DGs come and go; the council is legally responsible for the organization in ways the DG is not), and which certainly have the effect of concentrating power in the hands of the (elected) 
council. However, the DG, who, it is known, has a different view on how things should be run, is sitting in the meeting. Réal, one of the CA members, makes it clear that of course it is not a question of not having confidence in Bernard, but an association planning for its future cannot count on the eternal presence of one DG.

Réal: [...] on peut choisir la structure qui se rapporte à nous// le DG qu'on a tout de suite ou si jamais le DG venait à changer/ on aurait pas le choix t'sais? On ne pourrait plus réviser quelle sorte de structure on veut// donc

Pierrette: oui

Bernard: bon mais vu que

Réal: bien si on peut (faire?) beaucoup beaucoup de confiance comme c'est là à Bernard/ on peut choisir un modèle/ tu sais/ plus simplel/ mais si le prochain qui va le remplacer/ on ne peut pas le faire confiancel bien on ne voudra plus avoir le même non plus

Pierrette: mais ça ça pourrait changer

Réal: oui?

Pierrette: si on adopte une structure c'est pas ça qu'on cherche en ce moment? Une structure fixe pour le CA? On n'est pas pour commencer à changer à chaque fois qu'on a un différent $D G$

[...]

Émile: j'aimerais plus un consensus que consensus ouais? au lieu d'un vote

Pierrette: $\mathrm{mhm} /$ qu'est-ce que tu veux que je dise?

(Réal:... we can choose a structure which has to do with us (which fits us). The DG (DirectorGeneral) which we have right now or if ever the DG came to change, we wouldn't have a choice, y'know? We wouldn't be able to revise what kind of structure we want. So

Pierrette: yes

Bernard: ok but seeing as how

Réal: well yes we can (have?) lots lots of confidence as it is now with Bernard, we can choose a model, you know, a simpler one. But if the next one who replaces him, we can't trust him, well we wouldn't want the same one either

Pierrette: but that could change

Réal: yes?

Pierrette: if we adopt a structure isn't that what we're looking for right now? A fixed structure for the council? We aren't going to start changing every time we have a different DG

$[\ldots]$

Émile: I would prefer a consensus that consensus yeah? Rather than a vote

Pierrette: $\mathrm{mhm} /$ what would you like me to say?)

In addition to the face work regarding Bernard which is accomplished here in aid of the council's achievement of its goals, there are other dimensions worth commenting on. The actual discursive work is accomplished by Réal and Pierrette, providing a basis for the council to present itself as united and democratic, not under the thumb of its president or any one other member. Indeed, earlier in the transcript the elected president lays the groundwork for both supporting the particular model Réal and Pierrette are hinting at, namely a fixed structure independent of the particular personalities involved, and for building a consensus in support of such a structure. He does this explicitly: "J'aimerais plus un consensus que consensus ouais? au lieu d'un vote majoritaire (I would prefer a consensus to consensus yeah? rather than a majority vote) ". He also does this through control over turn-taking and topic introduction, and through the frequent use of personal disclaimers which situate the decision as a collective, not an individual one. He frequently uses $j e(\mathrm{I})$, and framing devices such as "suggesting", and "giving my opinion" as a means of stating his own position, which he makes available to the group without imposing it. He does not position himself as speaking for the group. In this excerpt, the building of the 
consensus is taken over by Réal and Pierrette, who do the actual framing of the models to be discussed and the facework needed to accomplish a collective decision with Bernard's consent.

The next turn in the sequence is the president's; he speaks at length about the importance of arriving at an informed collective decision. A few minutes later, he calls for a motion. Pierrette responds: "Mhm, qu'est-ce que tu veux que je dise? (Mhm, what do you want me to say?"). It is the president who formulates the formal motion which will then be reiterated and entered into the minutes as having been proposed by Pierrette and seconded by Réal. The association moves toward a more bureaucratized organization, less dependent on the charismatic leadership characteristic of the battles of the modernist discourse, more focussed on service to the community than fighting the community's battles with the dominant anglophone majority. Significantly it does so by eschewing charismatic models of leadership, preferring to accomplish its goals as a consensual bureaucratic organization.

This move gives the CA the legitimacy to go ahead and implement some changes. The first of these as we have seen involves the introduction of job descriptions, and with them contracts and performance evaluation methods. (Indeed, already at the April 1999 meeting a draft document was discussed containing all these elements; it ends : "Merci a l'avance de l'intérêt que vous portez au fonctionnement efficace [du centre] » (Thank you in advance for the interest you show in the efficient functioning of [the centre]).) Bernard resists this move, resulting in a painful stand-off lasting several months over the spring and summer of 1999. In the fall, a few months after the meeting discussed above, Bernard was dismissed from his position by the council, whose members one evening asked him for his keys and escorted him outside the building (the building which, it will be recalled, had served as headquarters for the school crisis of 1979-1981 in which Bernard had played such an important role).

The next thing the CA did was to take over Bernard's role as they drew up a job ad and proceeded to search for a replacement. The recruitment process was not completed until the following summer, and in the end the centre hired a young man from another community with experience in a variety of francophone organizations and institutions at the provincial level. During the time in which there was no DG, the CA went ahead with a number of changes.

In January 2000, it published a consultation document, seeking input regarding the orientation of the centre from anyone in the community (although specific people were also approached). Indeed, the document explicitly states that its form is the result of input not just from the $\mathrm{CA}$, but from the staff, from members of other organizations and from members of the community. It affirms as its "principes de base », " une approche démocratique et transparente », «la participation active des membres de la communauté », "l'inclusion et l'accessibilité » and «des liens avec d'autres partenaires dans la communauté » (its fundamental principles: A transparent and democratic approach, the active participation of members of the community; inclusivity and accessibility, and links with other partners in the community). Note the echo here of the criteria Bernard indicated would be used by the government to evaluate proposals for funding, the shift in the basis of legitimacy, and the opening up of access to positions of definition of what counts as the community and of what it should be doing.

This document also includes a draft mission statement: “ L'(Association) est un organisme catalyseur au service de la communauté francophone (The Association is a 
catalyzing organization at the service of the francophone community)". It is significant that the association feels the need at all to publish a mission statement, a genre with origins in the private sector. Such a statement makes the most sense in the context of the kind of discourse of public service and accountability which is typical of the new economy. And of course the content points directly to the same notions of service. Thus in what is probably the most significant single sentence for the establishment of its orientation, the association sends a clear message.

It reinforces it throughout the document with references to efficacité (efficiency), rentabilité (cost-effectiveness), marketing, partenariats (partnerships). At the end of the document, we find a list of key terms and their definitions; these include (in capital letters) : Catalyseur, communauté, francophone, imputabilité, inclusion, innovation, mission, organisme, principe, rentabilisation, service, transparence (catalyst, community, francophone, imputability, inclusiveness, innovation, mission, organization, principle, making something cost-effective, service, transparency).

The definition of francophone is: "Qui parle habituellement le français, au moins dans certains circonstances de la communication, comme langue premi ère ou seconde; comme groupe: Dans lequel le français est pratiqué en tant que langue maternelle, officielle ou véhiculaire (même si les individus ne parlent pas tous le français ) ) (who usually (habitually) speaks French, at least in certain communicative circumstances, as a first or a second language; as a group: In which French is used as mother tongue, as official language or as common language of communication (even if the individuals do not all speak French). In this view, it is the discursive space that has become important, and the language that is its key element, even if not everyone who participates in that space in fact speaks it. La francité is no longer a question of national identity, nor even of individual linguistic proficiency.

Finally, while the CA was busy building a consensus for a rather radically different view of collective identity, its community development arm became more and more active, as might be expected in conditions in which the centre relinquishes its role as single voice for a unified community. The community development organization is free to act, and act it does. Many articles are devoted to it in the local newspaper in the course of 2000, from one introducing it to the community (see above), to others concerning such activities as the establishment of a local government job centre focussing on bilingual positions (the area has a high unemployment rate; the idea is to facilitate local access to job information, highlighting the bilingual skills of the workforce), or brainstorming with the local francophone seniors' association about the development of a local museum in the context of a regional economic development focus on tourism.

Indeed, shortly afterwards a local historian and writer drew up some text for a website established by a provincial francophone association devoted to the development of heritage tourism. This region is one of five parcours (paths) across the province which were chosen to launch the project and the site.

La région peut se vanter d'être le berceau de la civilisation française en Ontario [...] Les liens commerciaux et militaires entre les Français et les Ouendats s'intensifièrent surtout avec la création de la mission [...] en 1639. [...] Une première vague de colons francophones permanents, composée des voyageurs Canadiens français et Métis, arriva en 1828, pour prendre les terres le long de la baie [...] Ȧ compter de 1840, d'autres Canadiens français, encouragés par le curé [...], se succédèrent en trois vagues pour coloniser des terres [...] 
Selon la légende du loup de [la localité], basée sur un fait historique, et racontée sous forme de pièce et ensuite de récit publié par le curé [nom] en 1955, les premiers groupes de colons francophones et leurs descendants vivaient isolés les uns des autres. Vers 1900, un loup mystérieux se mit à terroriser les habitants de la région en faisant d'importants ravages. La crainte du loup et les efforts pour le vaincre finirent par rallier les francophones, jusqu'alors divisés, à une cause commune. C'est [nom ], un borgne, qui, en évoquant l'aide du ciel, réussit enfin à abattre la bête possédée.

(The region can boast of being the cradle of French civilization in Ontario [...] Commercial and military links between the French and the Wendats intensified especially with the creation of a mission [...] in 1639. ... A first wave of permanent francophone colonizers, composed of French Canadian voyageurs and Métis, arrived in 1828, to take possession of lands along the bay [...] As of 1840, other French Canadians, encouraged by the parish priest [...], succeeded each other in three waves of colonization of the land [...] According to the legend of the wolf of [place name], based on historic fact, and told in the form of a play and then later in a text published by Father [name] in 1955, the first groups of francophone colonizers and their descendants lived isolated from one another. Around 1900, a mysterious wolf began to terrorize the inhabitants and caused serious damage. The fear of the wolf and efforts to overcome it ended up rallying the francophones who had hitherto been divided to a common cause. It was [name], a one-eyed man, who, calling for help from Heaven, was finally able to kill the possessed beast.)

This text uses a new medium, the internet; a new genre, the website; for a new purpose, selling authenticity; in a new context, the development of tourism for far-flung clients (especially from Québec, but also from Europe), as a way to retool the foundering economy of the region. Unlike the discourse of the centre itself, the website text reprises old themes: Tradition and history, and solidarity in the face of the aggressor (for the wolf, we might read anglophones), and links the newness of the genre to an unbroken line of local narrative practices (the legend, the play, the curé's text, now the website). It casts the relevant identity category (francophones) in contemporary terms, while obliterating its newness (in the 1800s people thought of themselves as French Canadians), and emphasizes the importance of ties to the indigenous population which are currently powerful elements of legitimation, while they would have been elements of shame not long ago (interestingly, during our fieldwork period, there was a sudden explosion of interest in the francophone population in acquiring official Métis status, a move which was strongly linked to "spoiled" identity only a few years ago, and still is for many people).

The action dimension of the local construction of community has, then, a particular form and content. It repositions the community both as fundamentally a discursive space and at the same time as the repository of newly valuable commodities: Bilingualism, and authentic identity. The TLM Bernard referred to in 1998 are largely still there, although the new structures put in place open the door to greater participation on the part of people whose membership might formerly have been hotly contested (Métis, anglophone spouses of francophones, second-language learners of French). They also shift the emphasis of community activity away from political lobbying and local cultural activities, and towards economic development in areas where the two commodities of bilingualism and authenticity are valued (tourism, communications, and, ironically, government departments and francophone institutions established on the basis of the old modernist, nationalist discourse). The relationship between language and identity is profoundly restructured (one doesn't have to speak French to sell authenticity, and one doesn't have to be authentic to speak French), as is the notion of monolithic identities, which suddenly become more easily multiplied (the 
bilingualism formerly stigmatized as a mark of assimilation is now valeur ajoutée; the spoiled identity of the Métis is now eagerly sought after, with people retracing genealogies and documents required for official recognition and the valued "Métis card").

These are multiple acts, in multiple sites, which link up together to provide a picture of how, perhaps, categories of collective identity change over time, how they reorient individual action, reposition actors, redefine the value of their resources. The collective acts Gramsci refers to turn out to be interactionally articulated, rather than massed; they are linked sets of small-scale interactions tied to institutionalized results like texts, hiring practices, job performance evaluations, and maybe less often spectacular demonstrations of the collective will.

\section{Postmodern identities and postmodern methods}

In a variety of different ways, actors at the heart of the production of discourse about la francité in this region (as in so many others), position and reposition themselves and the collective identity which orients their behaviour and their ways of constructing social reality. They do this individually partly, of course, but also, as I hope I have shown here, they do it through interactive modes which mobilize or exploit institutional structures and resources (the centre, the local newspaper, the heritage tourism association and its website, the community radio), although they connect with them in a variety of ways and through a variety of linguistic (and non linguistic) means. They talk to each other on the telephone, they meet in cafés, they sit alone at home and compose text, they participate in monthly executive committee meetings which use formalized rules governing the production of discourse (but which can be manipulated, shifted, temporarily ignored, or strongly adhered to), they read and discuss drafts of memos or consultation documents, and so on.

In order to capture how single cultural climates are constructed then, it is helpful to link up the life trajectories of actors, the ideological basis of the institutions and other social structures which constrain their lives (in the sense of presenting both obstacles and opportunities), and the here-and-now ways in which these structures happen, as processes, not things. We will inevitably miss bits, and it is difficult if not impossible to make claims of holism. Here I have opted instead to locate sites of discursive production and to try to trace their development and their relation to each other. In the specifics of interaction in these sites we can see how actors mobilize resources, and how they construct what can then become institutionalized discourses.

The specific case I have examined here is one of change without much resistance (except from Bernard, and we saw what happened to him). Clearly, the construction and reconstruction of discourses does not always happen so relatively smoothly, leaving open the question of why it should be smooth in some cases and rocky in others. That, however, is a question beyond the scope of this paper. Instead, I want to limit myself to raising the question of what might the sense of "hegemony" be if we understand it in terms of the collective construction of discourses in civil society. The answer, I think, lies in the connection between interactional and structuring processes, still ethnographically observable, and amenable to sociolinguistic analysis.

Consent seems partly to be about consent to pieces of processes whose full sweep may well be invisible to some or all participants; it is not clear to me, for example, that the 
members of the conseil d'administration knew, or could have articulated, all the dimensions of the acts of consent they performed in meetings. As Giddens points out, structuration is in part about unforeseen, and unforeseeable, consequences of actions which get taken up by others, elsewhere or later by the same people, under new conditions. It is therefore also about distributed knowledge (Cicourel 2002), with the important, Bourdieuian specification that the way knowledge (as a form of symbolic capital) is distributed is no accident, since knowledge is a form of power, regulated and fought over under conditions of inequality (Bourdieu 1982).

At the same time, as Cicourel and Bourdieu have also insistently argued, the knowledge involved is not necessarily conscious or articulable; it is as much embodied praxis as it is political debate. This raises additional questions about how hegemony works as consent (and even in relation to coercion), in particular that of the relationship between what we do, what we think we are doing and how we represent what we do to ourselves or to others.

Finally, we are left with questions about the characteristics of late modernity. The case presented here seems clearly to point to the relevance of flows, commodification and multiple affiliations in the discursive shifts underway, and in the reshaping of the basis of legitimacy of positions of power, from charisma to management, from essentialized identity to display of skills. What is relevant to us, now, may be the ways in which social change opens up possibilities for understanding both the general workings of hegemony, and the nature of the hegemonic forms and practices to which we may be about to consent.

\section{References}

Appadurai, Arjun (1996) Modernity at Large: Cultural Dimensions of Globalization. Minneapolis: University of Minnesota Press.

Bagaoui, Rachid, and Simon Laflamme (1997) Les organismes franco-ontariens face à la crise de l'Étatprovidence: Continuité et rupture. Revue du Nouvel-Ontario 21: 73-89.

Cicourel, Aaron (2002) Le raisonnement médical: Une approche socio-cognitive. Paris: Seuil.

Bourdieu, Pierre (1982) Ce que parler veut dire. Paris: Fayard.

Castells, Manuel (2000) The Information Age: Economy, Society and Culture. Oxford: Blackwell.

Cyr, Roger (1964) La Patente: Tous les secrets de la “maçonnerie” canadienne-française. L'Ordre de Jacques Cartier. Montréal: Éditions du Jour.

Farmer, Diane (1996) Les artisans de la modernité. Ottawa: Presses de l'Université d'Ottawa.

Giddens, Anthony (1984) The Constitution of Society. Berkeley, CA: University of California Press.

Gramsci, Antonio (1971) Q. Hoare and G. Smith (trans. and eds.), Selections from the Prison Notebooks of Antonio Gramsci. New York: International Publishers.

Heller, Monica (1999) Linguistic Minorities and Modernity: A Sociolinguistic Ethnography. London: Longman. 
Heller, Monica (in press) La Patente: Embryon de la modernisation. In M. Heller \& N. Labrie (eds.),Prise de parole: Langue, pouvoir et identité dans un monde en mutation. Montréal : HMH Hurtubise.

Heller, Monica, and Gabriele Budach (1999) Prise de parole: La mondialisation et la transformation des discours identitaires chez une minorité linguistique. Bulletin suisse de linguistique appliquée 69.2: 155-166.

Heller, Monica, and Normand Labrie (eds.) (in press) Prise de parole: Langue, pouvoir et identité dans un monde en mutation. Montréal: HMH Hurtubise.

Hobsbawm, Eric, and Terence Ranger (1983) The Invention of Tradition. Cambridge: Cambridge University Press.

Laliberté, G.-Raymond (1983) Une société secrète: l'Ordre de Jacques Cartier. Montréal: HMH Hurtubise. Martel, Marcel (1997) Le deuil d'un pays imaginé. Ottawa: Presses de l’Université d'Ottawa.

Philips, Susan (1998) Language ideologies in institutions of power: A commentary. In: B. Schieffelin, K. Woolard and P. Kroskrity (eds.), Language Ideologies: Practice and TheoryOxford: Oxford University Press, pp. 211-225.

Sylvestre, Paul-François (1980) Penetang: L'École de la résistance. Sudbury: Prise de parole. 